\title{
Effects of bovine follicular fluid inhibin on serum gonadotrophin concentrations in ewes during oestrus*
}

\author{
R. Medhamurthy, T. D. Carruthers and J. G. Manns \\ Department of Veterinary Physiological Sciences, Western College of Veterinary Medicine, \\ University of Saskatchewan, Saskatoon, Saskatchewan, Canada S7N OWO
}

\begin{abstract}
Summary. Experiments were conducted with ewes to investigate the effects of an enriched bovine follicular fluid inhibin preparation (INH) on gonadotrophin secretion after the onset of oestrus. Administration of INH $(10 \mathrm{mg}) 1 \mathrm{~h}$ after the onset of oestrus did not significantly alter the preovulatory FSH and LH surges or the second FSH peak. To determine the effects of INH on the second FSH surge, ewes were treated with saline $(\mathrm{N}=7)$ or INH $(\mathrm{N}=10)$ at $4 \mathrm{~h}(10 \mathrm{mg})$ and $24 \mathrm{~h}(5 \mathrm{mg})$ after the peak of the preovulatory LH surge. The second FSH surge was delayed about $24 \mathrm{~h}(P<0.05)$ in ewes treated with INH; however, the delay did not alter the interval to the next oestrus.

In a third experiment, 16 ewes were assigned to 4 groups in a $2 \times 2$ factorial with the main effects being ovariectomy at $4 \mathrm{~h}$ and INH treatment $(10 \mathrm{mg})$ at 4,20 and $36 \mathrm{~h}$ after the peak of the LH surge. Controls received sham ovariectomy and saline injection as appropriate. Ovariectomy resulted in a rapid increase in serum FSH but not LH and this was delayed $(P<0.05)$ by INH treatment. These results indicate that inhibin has a selective inhibitory action on FSH secretion in ewes and suggests that the second FSH surge results from increased basal FSH secretion due to decreased endogenous inhibin levels.
\end{abstract}

\section{Introduction}

The endocrine changes during the oestrous cycle of the ewe have been documented (Pant et al., 1977; Baird et al., 1981; Wheaton et al., 1984). There is a simultaneous surge of follicle-stimulating hormone (FSH) and luteinizing hormone ( $\mathrm{LH})$ after the onset of oestrus followed by a second surge of FSH alone $24 \mathrm{~h}$ later (Pant et al., 1977; Baird et al., 1981; Goodman et al., 1981). Increased secretion of oestradiol-17 $\beta$ before the onset of oestrus appears to be the stimulus for the simultaneous FSH and LH surges (Legan \& Karsch, 1979) but the cause and role of the second FSH surge is not clearly understood. It is unlikely that luteinizing hormone-releasing hormone (LHRH) is responsible for the second FSH surge in ewes since administration of antibodies to LHRH blocks the preovulatory gonadotrophin surge but not the second FSH surge (Narayana \& Dobson, 1978; McNeilly et al., 1984).

It is well established that inhibin, a glycoprotein hormone of gonadal origin, acts at the level of the pituitary gland to suppress FSH secretion selectively (Channing et al., 1985). Delayed onset of oestrus and decreased follicular growth have been reported for ewes and cows after administration of bovine follicular fluid (McNeilly, 1984; Quirk \& Fortune, 1986). The interpretation of these studies is complicated since bovine follicular fluid contains various other substances which may influence the actions of inhibin in vivo (Channing et al., 1985).

*Reprint requests to Dr J. G. Manns. 
Three experiments were conducted to determine (1) the effects of an enriched inhibin preparation from bovine follicular fluid on the preovulatory gonadotrophin surge and the second FSH surge; (2) the acute effects of ovariectomy on periovulatory FSH and LH concentrations; and (3) whether the FSH rise after ovariectomy could be prevented by inhibin.

\section{Materials and Methods}

\section{Animals}

Adult Finn $\times$ Rambouillet crossbred ewes ( $2-3$ years old) weighing $40-55 \mathrm{~kg}$ were studied during the breeding season (October 1985 to February 1986). Two or 3 days before each experiment, ewes were moved indoors and fitted with jugular catheters. Oestrus was synchronized by treating ewes for 14 days with progestagen-containing intravaginal sponges (Veramix, Tuco Products Company, Toronto, Canada). Oestrus was detected by hourly introduction of a vasectomized ram fitted with a marking harness.

\section{Preparation of inhibin from bovine follicular fluid}

Cow ovaries were collected on ice at a local abattoir and follicular fluid was aspirated and frozen until used. Fluid was thawed and adjusted to $\mathrm{pH} 7.5$ before fractionation by affinity chromatography on Matrex Gel Red A (Amicon Corporation, Lexington, U.S.A.) as described by Jansen et al. (1981). The most inhibin-active fraction, INH, was desalted on Sephadex G-25 and stored frozen at $-15^{\circ} \mathrm{C}$ until used. In earlier studies (Medhamurthy et al., 1985) batches of INH prepared as described had $\sim 25$ times more activity/mg protein than did the crude follicular fluid when bioassayed in a rat pituitary cell culture system (Eddie et al., 1979). The inhibin bioactivity of the INH preparations used in the present experiments was not determined.

\section{Experimental designs}

Experiment 1 . The objective of this experiment was to determine the effects of INH on the preovulatory gonadotrophin surge. At $1 \mathrm{~h}$ after the onset of oestrus, ewes were treated with saline $(0.85 \%(\mathrm{w} / \mathrm{v}) \mathrm{NaCl}$ buffered with $0.05 \mathrm{M}$ phosphate, $\mathrm{pH}=7 \cdot 2 ; \mathrm{N}=6)$ or INH protein (10 mg i.v.; $\mathrm{N}=5)$. Blood samples $(\sim 3.5 \mathrm{ml})$ were collected every hour for 3 days after the onset of oestrus.

Experiment 2. The effects of INH on the second FSH surge were investigated in this experiment. After detection of oestrus with a vasectomized ram, blood samples were collected every $2 \mathrm{~h}$ and a rapid radioimmunoassay was used to detect the LH surge. Ewes were treated with saline $(\mathrm{N}=7)$ or INH $(\mathrm{N}=10)$ at $4 \mathrm{~h}(10 \mathrm{mg}$ i.m.) and $24 \mathrm{~h}(5 \mathrm{mg}$ i.m. after the peak of the preovulatory LH surge. Blood samples were collected every $2 \mathrm{~h}$ for 4 days.

Experiment 3 . This experiment tested the hypothesis that the second FSH surge is the consequence of increased basal FSH secretion due to decreased ovarian negative feedback. As in Exp. 2, the LH surge was detected using a rapid LH radioimmunoassay. Ewes $(\mathrm{N}=16)$ were assigned to a $2 \times 2$ factorial with the main effects being (1) bilateral ovariectomy (Ovex) or sham surgery in which the ovaries were exposed and handled but not removed (Sham) and (2) INH or saline treatment. Surgery was performed at $4 \mathrm{~h}$ and $\mathrm{INH}(10 \mathrm{mg}$ i.m.) was injected at 4,20 and $36 \mathrm{~h}$ after the peak of the preovulatory LH surge. Blood samples were collected every $2 \mathrm{~h}$ for 4 days.

\section{Gonadotrophin assays}

Serum FSH was measured with the oFSH kit and protocol supplied by the National Hormone and Pituitary Program, NIADDK, Bethesda, MD, U.S.A. (Technical Report No. 156) and used with minor modification. The total assay incubation volume was $0.5 \mathrm{ml}$ instead of $0.7 \mathrm{ml}$ and the antiserum to FSH (NIADDK-oFSH-S14) was used at a 1:120 000 final tube dilution. The sensitivity of the assay was $0.06 \mathrm{ng}$ NIH-oFSH-RP-1/assay tube. The inter-and intraassay coefficients of variation were $7 \cdot 1$ and $7 \cdot 8 \%$ ( $n=9$ assays).

Serum LH assays were carried out according to the protocol of Niswender et al. (1968) with minor modification. Serum samples were incubated simultaneously with first antibody (NIH-oLH-S12) and ${ }^{125}$ I-labelled LH (LHLER 1716-II) for 1 day instead of sequentially over 2 days. The sensitivity of the assay was $0 \cdot 1 \mathrm{ng}$ NIAMDD-oLH-24/ assay tube. The intra- and inter-assay coefficients of variation were 5.9 and $7.3 \%(n=9$ assays).

Amongst ewes there was wide variation between the detected onset of oestrus and the start of the preovulatory gonadotrophin surge (range $=-6$ to $23 \mathrm{~h}$ ). However, the interval between the onset of the preovulatory LH surge and the onset of the second FSH surge was relatively constant. Therefore, in Exps 2 and 3, a rapid LH assay was used to determine the onset of the LH surge which was then used to predict accurately the onset of the second FSH surge. The assay reagents were the same as those used for the regular LH assay. The first antibody (1:50 000 instead of 1:300 000) and the second antibody were incubated for 1 day at room temperature. To the pre-precipitated antibody mixture, plasma from a heparinized aliquant of the appropriate blood samples and labelled hormone were added and incubated 
for $2 \mathrm{~h}$ at $37^{\circ} \mathrm{C}$ in a shaking waterbath. At the end of $2 \mathrm{~h}$, the bound hormone was separated by centrifugation and the radioactivity was counted. Each assay contained high and low control sera as well as an abbreviated standard curve.

\section{Statistics}

The magnitudes of the FSH and LH preovulatory surges were subjected to analysis of variance (ANOVA). Serum FSH and LH concentrations following the preovulatory surge were subjected to ANOVA with repeated measures following $\log _{10}$ transformation to correct for heterogeneous variance as required. Comparisons between treatments or over time were made using Tukey's HSD multiple range test and the appropriate error term from the ANOVA (Gill, 1978). For Figs 3 and 4, data from 3 samples taken over a 6-h period were averaged on a within-ewe basis before calculation of the means and s.e.m. which are plotted on the centres of the pooled periods.

\section{Results}

Experiment 1: effects of INH on the preovulatory surge

The interval between sponge removal and the onset of behavioural oestrus was $32.7 \pm 1.5 \mathrm{~h}$ $(\mathrm{N}=11$, mean \pm s.e.m.). The start of the preovulatory gonadotrophin surge ranged from an estimated $-6 \mathrm{~h}$ before until $23 \mathrm{~h}$ after the detected onset of oestrus. Figure 1 illustrates the mean serum FSH and LH concentrations after the onset of oestrus in ewes treated with saline or INH; there was no apparent influence of interval from treatment to the onset of the preovulatory surge therefore data are aligned to the preovulatory LH peak. The mean magnitudes of the preovulatory FSH surges were
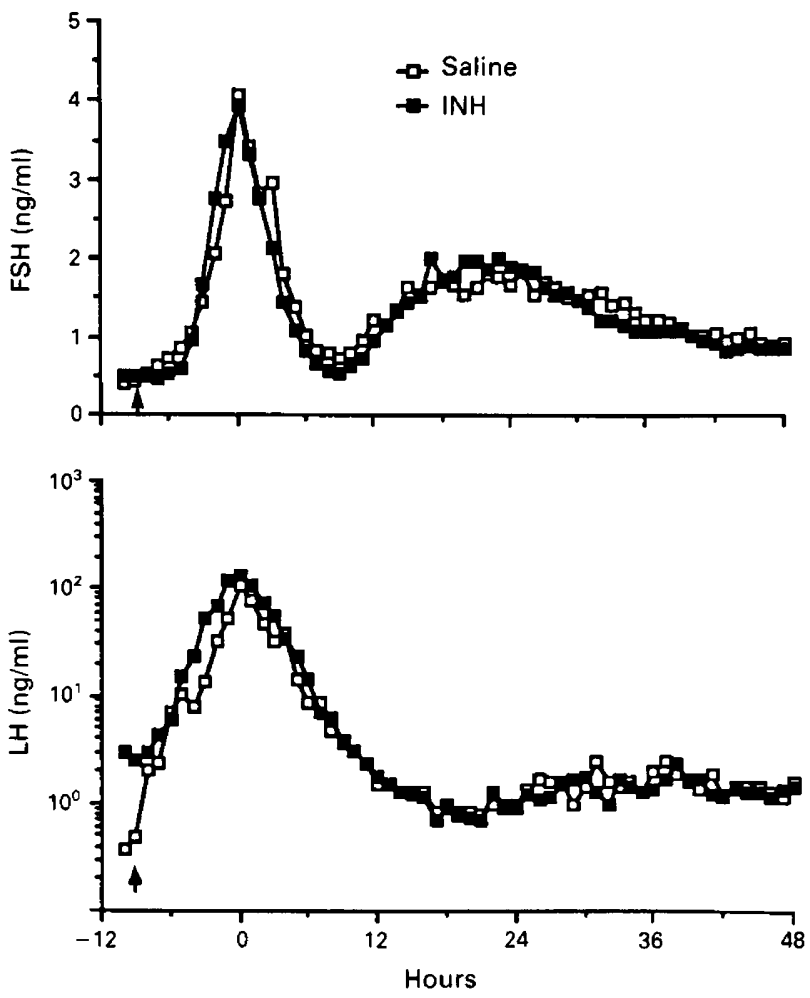

Fig. 1. Changes in mean serum concentrations of FSH and LH after i.v. injection of saline $(\mathrm{N}=6)$ or $10 \mathrm{mg}$ INH $(\mathrm{N}=5)$ at $1 \mathrm{~h}$ after the onset of behavioural oestrus. Serum FSH and LH concentrations were aligned to the LH peak $(0 \mathrm{~h})$. The arrow indicates the mean time of injection relative to the $\mathrm{LH}$ peak. 


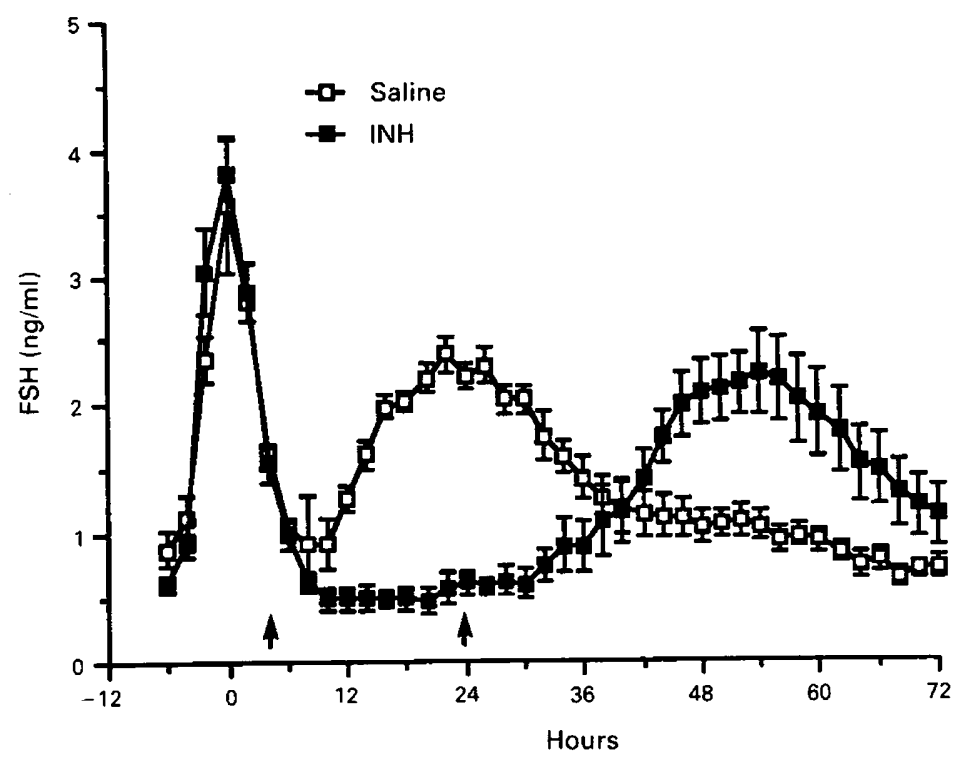

Fig. 2. Serum concentrations (mean \pm s.e.m.) of FSH before and after i.m. injection of saline $(\mathrm{N}=7)$ or INH (5 and $10 \mathrm{mg} ; \mathrm{N}=10)$ at 4 and $24 \mathrm{~h}$ after the peak of the preovulatory LH surge. Serum FSH and $\mathrm{LH}$ concentrations were aligned to the $\mathrm{LH}$ peak $(0 \mathrm{~h})$. Arrows indicate the time of treatment.

similar for ewes treated with saline or INH $(4 \cdot 1 \pm 0.4$ and $4 \cdot 0 \pm 0.4 \mathrm{ng} / \mathrm{ml})$. The second FSH surge began immediately after the preovulatory gonadotrophin surge in 9 of 11 ewes. INH treatment did not affect FSH concentrations after the preovulatory surge $(P>0 \cdot 2)$.

The preovulatory LH surges were similar in ewes treated with saline or INH $(102 \pm 21$ and $136 \pm 15 \mathrm{ng} / \mathrm{ml}$ respectively) $(P>0 \cdot 2)$ as were $\mathrm{LH}$ concentrations after the surge.

\section{Experiment 2: effects of INH on the second FSH surge}

Mean serum FSH concentrations for 4 days after the onset of oestrus are shown in Fig. 2. The magnitudes of the preovulatory FSH surges were similar in saline- and INH-treated ewes $(3 \cdot 6 \pm 0 \cdot 5$ and $3.8 \pm 0.3 \mathrm{ng} / \mathrm{ml}$ respectively). Serum FSH concentrations in saline-treated ewes increased to a maximum $24 \mathrm{~h}$ after the peak of the preovulatory FSH surge in all 7 ewes. In ewes treated with INH, serum FSH values from 12 to $34 \mathrm{~h}$ after the preovulatory surge were similar to those seen before the surge and were lower $(P<0.05)$ than the concentrations during the same period in control ewes. Serum FSH concentrations 44-64 h after the preovulatory FSH surge were higher $(P<0.05)$ in ewes treated with INH than in saline-treated ewes. By $72 \mathrm{~h}$ after the preovulatory gonadotrophin surge serum FSH concentrations were not different $(P>0 \cdot 10)$ in ewes treated with saline or INH.

The magnitude of the preovulatory LH surge $(112 \pm 20$ and $112 \pm 16 \mathrm{ng} / \mathrm{ml})$ and mean serum LH concentrations after the surge were similar in both treatment groups (data not shown).

\section{Experiment 3: effects of ovariectomy and INH on periovulatory gonadotrophin concentrations}

Figure 3 illustrates the mean serum FSH concentrations for the 4 subgroups. The magnitude of the preovulatory FSH surge did not differ between the groups. In the Sham + saline controls, the second FSH surge appeared reduced in magnitude and duration relative to those seen in Exps 1 and 2. Serum FSH increased rapidly after surgery in Ovex + saline ewes. Treatment with INH delayed 
(a)

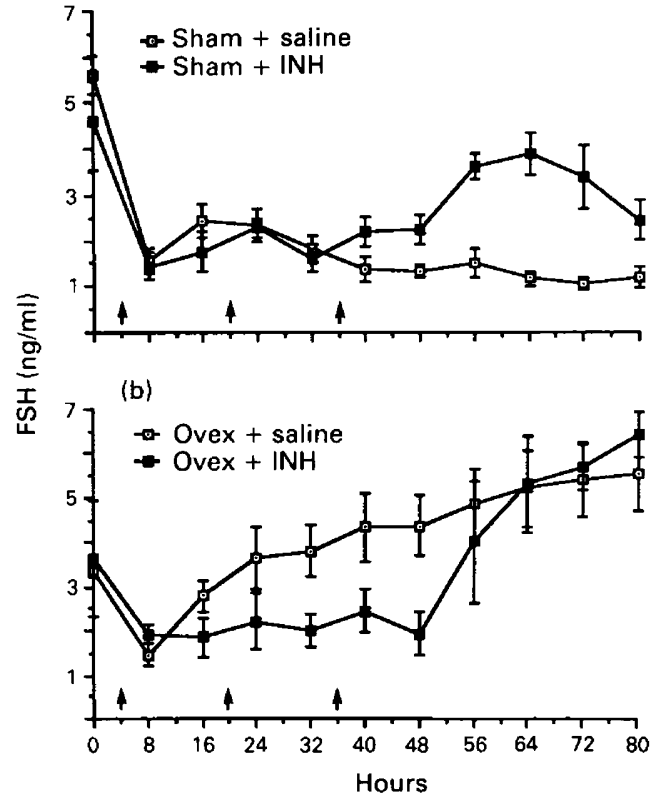

Fig. 3. Serum FSH concentrations (mean \pm s.e.m.; $N=4$ /subgroup) in ewes treated with Saline or an enriched bovine follicular fluid inhibin preparation (INH, $10 \mathrm{mg}$ ) at 4,20 and $36 \mathrm{~h}$ after the peak of the preovulatory LH surge and undergoing (a) sham surgery (Sham) or (b) ovariectomy (Ovex) at $4 \mathrm{~h}$. Treatments are indicated with arrows.

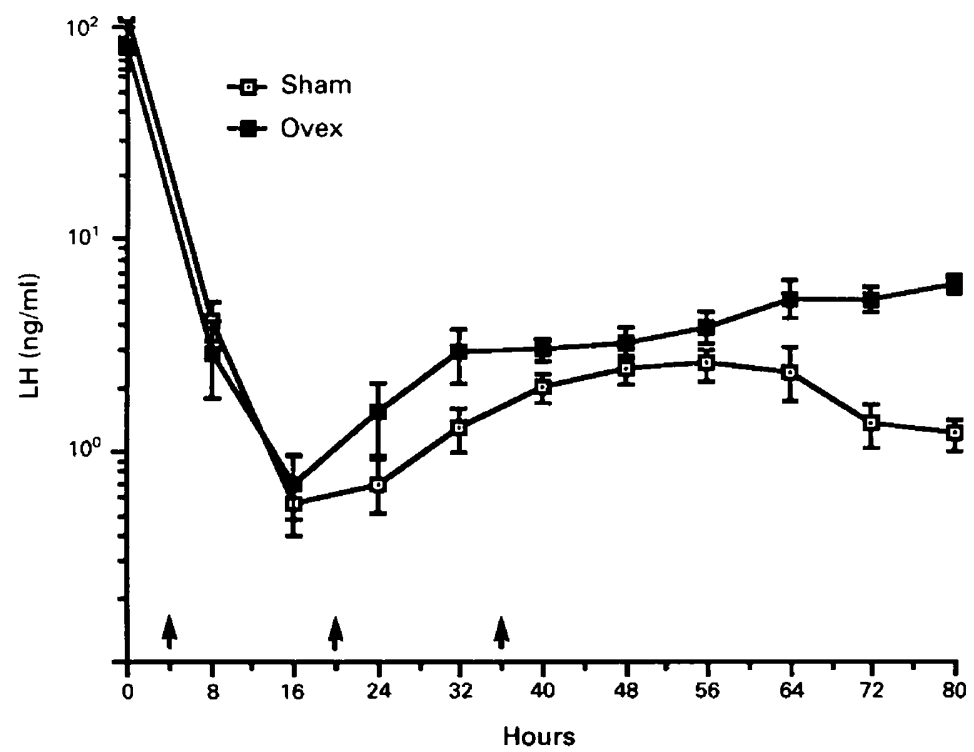

Fig. 4. Serum LH concentrations (mean \pm s.e.m.; $N=8$ ) in ewes undergoing sham surgery (Sham) or bilateral ovariectomy (Ovex) at $4 \mathrm{~h}$ after the peak of the preovulatory surge.

for about $40 \mathrm{~h}$ the second FSH surge in the Sham + INH group and the increase after surgery in the Ovex + INH group. Serum FSH appeared to increase in a similar manner at the onset of the second surge and immediately after ovariectomy. 
The magnitudes of the preovulatory LH surge were similar for the four subgroups. Mean serum LH concentrations after the peak of the preovulatory surge were not affected by INH treatment nor were there significant interactions involving INH; therefore pooled results for Sham and Ovex treatments are shown in Fig. 4. There was a tendency for mean serum LH in Ovex ewes to be greater than in Sham ewes beginning $20 \mathrm{~h}$ after surgery but a significant increase $(P<0.05)$ was not present until $60 \mathrm{~h}$.

\section{Discussions}

The results demonstrate that INH, an enriched inhibin preparation from bovine follicular fluid, can delay the second FSH surge and the FSH increase after bilateral ovariectomy in ewes but did not affect the preovulatory FSH surge when administered after the onset of oestrus. Furthermore, the results show that INH did not alter serum LH concentrations during or after oestrus or after ovariectomy. The dose of INH used in the present experiments was based on results from previous studies in which 5 and $10 \mathrm{mg}$ doses of INH caused $45-50 \%$ suppression of FSH in ovariectomized ewes (Medhamurthy et al., 1985).

Dobson \& Ward (1977) reported that administration of pentobarbitone after the onset of oestrus inhibited the release of $\mathrm{LH}$ but prolonged the release of FSH during the expected time of the preovulatory FSH and LH surge. Experiment 1 was conducted to determine whether INH could selectively block the preovulatory FSH surge. Our failure to observe an effect on the preovulatory FSH surge may have been because events responsible for the initiation of the gonadotrophin surge had taken place before INH could act. Irrespective of the timing of the INH treatment relative to the onset of the preovulatory gonadotrophin surge there was no apparent influence of INH in any ewe. Administration of inhibin preparations at frequent intervals after luteolysis induced by prostaglandin F- $2 \alpha$ delays the onset of oestrus and the initiation of the preovulatory gonadotrophin surge (McNeilly, 1984; Quirk \& Fortune, 1986). Furthermore, serum oestradiol-17 $\beta$ concentrations are lower in animals with delayed oestrus (Quirk \& Fortune, 1986) and increased oestradiol-17 $\beta$ secretion at oestrus appears to initiate the gonadotrophin surge (Legan \& Karsch, 1979). Perhaps oestradiol-17 $\beta$ secretion had increased before INH treatment and so INH could not reverse the positive feedback effect of oestradiol on the gonadotrophins. Stouffer \& Hodgen (1980) reported that charcoal-extracted follicular fluid from pigs did not block the mid-cycle FSH surge in rhesus monkeys when administered after establishment of the positive feedback effect of oestradiol.

The significant delay in the onset of the second FSH surge due to INH treatment in Exp. 2 suggests that endogenous inhibin concentrations may be depressed before and during the second FSH surge. Therefore, when exogenous inhibin was administered the second FSH surge was delayed until the exogenous inhibin had been cleared. Several workers have noted a rebound FSH secretion after inhibin-induced FSH suppression in intact animals (Wallace \& McNeilly, 1985; Quirk \& Fortune, 1986). DePaolo et al. (1979) suggested that treatment with inhibin suppressed FSH and disrupted follicular development; then, at the end of treatment FSH concentrations increased due to the clearance of exogenous inhibin and the lack of endogenous inhibin secretion.

The increase in FSH that occurred within hours after ovariectomy was similar to the initial onset of the second FSH surge. However, serum FSH concentrations continued to increase instead of returning to basal concentrations as in intact ewes. Findlay \& Cumming (1977) reported a selective increase in FSH within 5.5-12 h after unilateral ovariectomy in sheep during the luteal phase. This study and the results in Exp. 3 suggest that the initial FSH increase after unilateral or bilateral ovariectomy is similar in ewes and that this selective FSH rise is probably due to breakdown of the negative feedback of the gonads on the pituitary. Our failure to detect an increase in $\mathrm{LH}$ until $60 \mathrm{~h}$ after ovariectomy was probably a result of the small number of animals and inherent variability of pulsatile $\mathrm{LH}$ secretion in ovariectomized animals.

In ewes, antibodies to LHRH did not block the second FSH surge (Narayana \& Dobson, 1978), indicating that it is not under the control of LHRH. Oestradiol and progesterone were only partly 
effective in preventing or reversing the increase in serum FSH after gonadectomy in ewes (Goodman et al., 1981), suggesting that removal of the gonads may trigger the selective rise in FSH because of a break in the negative feedback system between FSH and a non-steroidal ovarian hormone, presumably inhibin.

As previously suggested by Grady et al. (1982), the results of the present experiments support the concept that after ovulation and consequent loss of the largest follicles, there is a temporary interruption in suppression of FSH synthesis and/or release from the pituitary which results in increased serum FSH concentrations. This increase in serum FSH causes increased follicular growth and these follicles then secrete increased amounts of inhibin which acts on the pituitary to reduce FSH secretion. In ewes, the precise function of the second FSH surge is not yet understood. Cahill et al. (1981) observed a positive correlation between the magnitude of the second FSH surge and the number of antral follicles present 17 days later. Therefore, the second FSH surge in the ewe may be involved in the recruitment of follicles for subsequent ovulations.

We thank the National Pituitary Agency (U.S.A.), Dr A. F. Parlow of NIAMDD, Dr L. E. Reichert and Dr G. D. Niswender for reagents used in the assays. This work was supported by grants from NSERC, the Alberta Agricultural Research Trust and the Saskatchewan Horned Cattle Trust Fund.

\section{References}

Baird, D.T., Swanston, I.A. \& McNeilly, A.S. (1981) Relationship between $\mathrm{LH}, \mathrm{FSH}$, and prolactin concentration and the secretion of androgens and estrogens by the preovulatory follicle in the ewe. Biol. Reprod. 24, 1013-1025.

Cahill, L.P., Saumande, J., Ravault, J.P., Blanc, M., Thimonier, J., Mariana, J.C. \& Mauleon, P. (1981) Hormonal and follicular relationships in ewes of high and low ovulation rates. J. Reprod. Fert. 62, 141-150.

Channing, C.P., Gordon, W.L., Lui, W.-K. \& Ward, D.N. (1985) Physiology and biochemistry of ovarian inhibin. Proc. Soc. exp. Biol. Med. 178, 339-361.

DePaolo, L.V., Hirschfield, A.N., Anderson, L.D., Barraclough, C.A. \& Channing, C.P. (1979) Suppression of pituitary secretion of follicle-stimulating hormone by porcine follicular fluid during pro-oestrus and oestrus in the rat: effects on gonadotrophin and steroid secretion, follicular development and ovulation during the following cycle. J. Endocr. 83, 355-368.

Dobsen, H. \& Ward, W.R. (1977) Alterations in plasma gonadotrophin patterns caused by sodium pentobarbitone in ewes at oestrus and anoestrous ewes after infusion of oestradiol. J. Endocr. 75, 109-118.

Eddie, L.W., Baker, H.W.G., Higginson, R.E. \& Hudson, B. (1979) A bioassay for inhibin using pituitary cell cultures. J. Endocr. 81, 49-60.

Findlay, J.K. \& Cumming, I.A. (1977) The effect of unilateral ovariectomy on plasma gonadotrophin levels, estrus and ovulation rate in sheep. Biol. Reprod. 17, $178-183$.

Gill, J.L. (1978) Design and Analysis of Experiments in the Animal and Medical Sciences, Vols 1 \& 2. The lowa State University Press, Ames.

Goodman, R.L., Pickover, S.M. \& Karsch, F.J. (1981) Ovarian feedback control of follicle-stimilating hormone in the ewe: evidence of selective suppression. Endocrinology 108, 772-777.
Grady, R.R., Charlesworth, M.C. and Schwartz, N.B. (1982) Characterization of the FSH-suppressing activity in follicular fluid. Recent Prog. Horm. Res. 38, 409-456.

Jansen, E.H.J.M., Steenbergen, J., de Jong, F.H. \& van der Molen, H.J. (1981) The use of affinity matrices in the purification of inhibin from bovine follicular fluid. Molec. cell. Endocr. 21, 109-117.

Legan, S.J. \& Karsch, F.J. (1979) Neuroendocrine regulation of the estrous cycle and seasonal breeding in the ewe. Biol. Reprod. 20, 74-85.

McNeilly, A.S. (1984) Changes in FSH and pulsatile secretion of LH during the delay in oestrus induced by treatment of ewes with bovine follicular fluid. $J$. Reprod. Fert. 72, 165-172.

McNeilly, A.S., Fraser, H.M. \& Baird, D.T. (1984) Effect of immuno-neutralization of LH releasing hormone on $\mathrm{LH}, \mathrm{FSH}$ and ovarian steroid secretion in the preovulatory phase of the oestrous cycle in the ewe. $J$. Endocr. 101, 213-219.

Medhamurthy, R., Carruthers, T.D. \& Manns, J.G. (1985) Secretion of gonadotrophins following injection of inhibin in OVX ewes: effect of LHRH. Biol. Reprod. 32, Suppl. 1. 107, Abstr.

Narayana, K. \& Dobson, H. (1978) Effect of administration of antibody against GnRH on preovulatory LH and FSH surges in the ewe. J. Reprod. Fert. 57, 65-72.

Niswender, G.D., Reichert, L.E., Midgley, A.R., Jr \& Nalbandov, A.V. (1968) Radioimmunoassay for bovine and ovine luteinizing hormone. Endocrinology 84, $1166-1173$.

Pant, H.C., Hopkinson, C.R.N. \& Fitzpatrick, R.J. (1977) Concentration of oestradiol, progesterone, luteinizing hormone and follicle-stimulating hormone in the jugular venous plasma of ewes during the oestrous cycle. J. Endocr. 73, 247-255. 
Quirk, S.M. \& Fortune, J.E. (1986) Plasma concentrations of gonadotrophins, preovulatory follicular development and luteal function associated with bovine follicular fluid-induced delay of oestrus in heifers. J. Reprod. Fert. 76, 609-621.

Stouffer, R.L. \& Hodgen, G.D. (1980) Induction of luteal phase defects in Rhesus monkeys by follicular fluid administration at the onset of the menstrual cycle. $J$. clin. Endocr. Metab. 51, 669-671.
Wallace, J.M. \& McNeilly, A.S. (1985) Increase in ovulation rate after treatment of ewes with bovine follicular fluid in the luteal phase of the oestrous cycle. $J$. Reprod. Fert. 73, 505-515.

Wheaton, J.E., Mullet, M.A. \& Cornelius, S.G. (1984) Plasma follicle stimulating hormone and luteinizing hormone patterns during the estrous cycle of ewes. Theriogenology 21, 989-999.

Received 31 December 1986 